\title{
On NGOs' Role in the Development of Business Ethics in Slovakia
}

\author{
By Anna Remišová* \\ Anna Lašákovát
}

\begin{abstract}
The socio-economic transformation after the fall of communism in Slovakia took place without anchoring new economic subjects in corporate social responsibility. Private companies and state authorities showed little interest in business ethics, so it stayed marginalized. Now, after more than two decades of development for business ethics in Slovakia, an absence of a systematic support for business ethics still pertains. Nonetheless, some initiatives have already been implemented to sustain ethics in business and typically the impetus for these initiatives was given by non-governmental organizations (NGOs). This paper investigates the influence of nine prominent NGOs operating in Slovakia on the development of business ethics in the current Slovak business environment. Based on indepth analysis of NGOs' documentation to projects undertaken in Slovakia throughout the last two decades and semi-structured interviews with the respective NGOs' leaders, the article critically analyzes the nature, scope and effects of NGOs' activities with respect to the advancement of business ethics in companies in Slovakia. Results of this qualitative inquiry suggest NGOs' activities add value mainly on the macro level, i.e. focusing on the fight against corruption, anti-social and illegal activities in state and public administration, promoting democracy and transparency. There are also several inspirational initiatives to expand business ethics on the mezzo level, such as guidelines for introducing corporate codes of ethics, a corporate governance code, an anticorruption charter, or whistle-blowing channels. There is no doubt these initiatives are important because every stimulus for integrating ethics and economics is rare and valuable in Slovak cultural conditions. However, activities of NGOs lack a broader view of the necessity of ethical regulation in business. In particular, results indicate shortage of attention to the control of illegal and unethical activity within the company, to unethical leadership and related negligence of the tone at the top of companies.
\end{abstract}

Keywords: Business Ethics, CEE, Compliance, Ethical Regulation, NGOs, Slovakia.

\section{Introduction}

This study presents preliminary results of qualitative research strand that is a part of a large multi-method comprehensive research on business ethics in Slovakia. The mission of this research project is to provide Slovak companies with particular mechanisms of business ethics application. Based on the critical analysis of the current state of ethics in Slovak business, of the cutting-edge scientific knowledge and of practical experience in Europe and globally, the main aim of this project is to create a comprehensive Integrated model for long-term

${ }^{*}$ Professor, Comenius University in Bratislava, Faculty of Management, Slovakia.

${ }^{\dagger}$ Associate Professor, Comenius University in Bratislava, Faculty of Management, Slovakia. 
development of business ethics for companies operating in the Slovak business environment with taking into account the size of companies according to the number employees.

One of the objectives of our research was to find out what pro-ethical activities took place in the Slovak business environment already and what impact have had these activities on the business ethics development. This article focuses on the analysis of activities and projects of NGOs operating in Slovakia aimed at promoting business ethics. The aim of the article is to map specific NGOs' projects that were aimed at promoting business ethics and to gain insights into NGOs' unique experiences resulting from these projects.

Why NGOs? Prior studies on ethics in the Slovak business environment (Remišová 2011, Remišová 2015, Remišová et al. 2016) suggest a long-term absence of a systematic state-led initiatives and support for ethical business. Besides few individual business entities, the non-profit organizations were those who have actually begun to spread the idea of corporate responsibility in business, the need for transparency and respect for law. Since the fall of communism, NGOs in Slovakia have played an important role in the development of civil society and democracy in the 1990s. In social life, the NGOs emerged during the transformation, and became guarantors of emerging democracy, civic engagement, transparency as well as advocates of the victims of state machinery. They have become active actors of social life at the macro level and have urged for new values in public life. Transformational political and economic processes have also highlighted the issues of ethics in business, but at the beginning of the transformation, the governmental institutions together with the business entities were not ready to accept, apply and develop the idea of ethics in business.

\section{Some Insights on the Role of NGOs in Society}

In the extant literature, various approaches to classification of NGOs are present. NGOs are classified according to the areas in which they operate (e.g. education, health, human rights, civil society). Alternatively, NGOs are differentiated based on the locality in which they operate (e.g. local, national, global). Arenas et al. (2009) differentiate between "membership organizations" and "non-membership organizations". Whatever the categorization of NGOs is, their common denominator is that they are social institutions that are, on the one hand, independent of the government, and on the other hand, they defend universal values, the interests of individuals and collectives or members of civil society and the civil society as a whole, while, at the same time, they are not established to generate profits. Considering this, NGOs are often defined as "nonprofit organizations", "civil society organizations" or "the third sector" (Arenas et al. 2009). In our cultural environment, all three terms are considered synonymous.

Although in the past various cultural, political, social, economic and sportsrelated activities of Slovak citizens in opposition to the then ruling power were witnessed, NGOs, as specific entities operating in Western democracies after 1945 , were a totally new social phenomenon in our country. In the previous 
political regime, this type of social institution did not exist. A similar experience with NGOs was described by Polish authors Reichel and Rudnicka (2009).

In Western democracies, the expansion of NGOs increased after the $2^{\text {nd }}$ World War. Their extraordinary boom, however, is linked to the globalization of the economy and the end of the Cold War. The unprecedented economic power of corporations, their global impact on population and natural environment across the globe, together with the loss of power of national states to stand up against this new authority, has sparked an enormous increase in the number of NGOs. These, as social capital entities (Putnam et al. 1993), have had the potential to face the dominating pressure of corporations, capital and market. For instance, a number of NGOs have been active in the standards and verification industries. This work has been instrumental in benchmarking companies against external standards like the Global Reporting Initiative (GRI). As for the later, the GRI is now institutionalized as the leading global framework for voluntary corporate environmental and social reporting. The inherent ideas of GRI - sustainability and corporate social responsibility - have become an inseparable part of the international discourse on the role of corporations in society thanks to its promotion by various agents such as multinational corporations, intergovernmental organizations, civil society and social movement groups as well as the NGOs (Weber and Soderstrom 2015). According to Levy et al. (2010), the success of GRI can be attributed to institutional entrepreneurs, also to NGOs. This means that NGOs could be understood as agents that have helped to destroy nonmarket institutions by providing innovations to their external environment and establishing new market conditions along with their regular activities ( $\mathrm{Li}$ et al. 2006). Nevertheless, GRI has fallen short to empower NGOs as their role in the whole process "is inherently constrained by the structural power of wider institutions and by the compromises required to initiate change" (Levy et al. 2010: 88).

Especially in the 1980s and 1990s, relationship between NGOs and business subjects was characterized as confrontational in the literature; furthermore, also the relations between NGOs and corporations were viewed as quite adverse (Baur and Palazzo 2011, Baur and Schmitz 2012, Burgos 2013, Laasonen et al. 2012). This quality of relationship between NGOs and business began to change at the beginning of the millennium; a shift from confrontation between NGOs and business towards their cooperation has begun. As Wieland notes, "after a phase of confrontation between NGOs and business actors, the turn of the millennium has brought the breakthrough of a new, more incisive and conciliatory approach" (Wieland 2009: 89). Later, a new pattern of association emerged, namely the "cross-sectoral partnership", i.e. cooperation of NGOs, government and business (Egels-Zanden and Wahlqvist 2007). This new type of relationship was labelled as "new governance" (Moon 2002). It denotes a situation when the public, private and third sectors associate to discuss and improve private sector regulation (Choi et al. 2005, Kourula and Halme 2008).

NGOs have been active in co-creating global external ethical standards for business. One of the many examples is the "soft" standard on social responsibility ISO 26000 launched in 2005. Experts and observers from government, industry, labor and consumer organizations, academia and the NGOs have been working 
intensively on reaching consensus on corporate social responsibility and in the end created an internationally applicable set of minimum norms for company conduct; and have set also the procedural standards on how these substantive standards should be applied (Jimena 2009).

An increase in interaction regarding corporate social responsibility between NGOs and companies was noted also by Jonker and Nijhof (2006) who state that whereas in the past companies interacted primarily with shareholders, customers and local regulators, today CSR necessitates the involvement of actors from beyond companies' usual production and consumption systems. Companies "need to position themselves in the changing interaction processes with NGOs and private and public actors through which the new responsibilities are articulated" (Jonker and Nijhof 2006: 457). Based on Waddell's (1999) work, Jonker and Nijhof (2006) discuss the mutual alignment in expectations of NGOs and businesses with clear complementing areas of their interests, resources and competencies. Business is competent to provide finances, industry knowledge, reputation, business networks and management skills, while NGOs are able to assist with issue development, community networks, trust generation and inspirational and volunteer assets.

Similarly, Jamali and Keshishian's (2009) research also supports the view of businesses-NGOs partnership as an alliance rooted in the need to gain crucial complementary resources in the pursuit of joint objectives. In their research they showed that it is possible for companies and NGOs to build working partnerships and capitalize on a set of matching resources offered through the partnership. Through collaborative arrangements, NGOs and companies can "tackle CSR challenges that they could not have addressed in isolation" (Jamali and Keshishian 2009: 289).

Another example of how NGOs assist the corporate ethical conduct is offering their partnership to corporations in development projects and voluntary regulations promotion. As Noh (2017) argues, though some accomplishments were gained, by now no fundamental change has happened in the way how corporations operate specifically in the Third countries. Noh (2017) concludes NGOs should maximize power through creating information flow and building global networks.

One of the most recent global movements focused on the environmental and long-term economic issues, the UN 2030 Agenda for Sustainable Development (UN SDGs), inspires collaborative projects of intergovernmental organizations, governments and NGOs to enact and standardize corporate behavior for a greater concern for the wellbeing of social groups, regions, or entire societies (Bergman et al. 2017).

Nevertheless, Asi and Williams (2018) show that the UN SDGs are complex and ambitious and even in the most stable environments, it is difficult to achieve full completion of related goals, while in specific conflict-affected environments, this challenge is much greater. Therefore, they call for a greater emphasis on collaboration and proactivity of NGOs and other relevant stakeholders.

Similarly, Xiao et al. (2017) state that to fully utilize the potential of the UN SDGs, new partnerships between the UN, the World Bank, NGOs and other 
private and public organizations and coordination across all the sectors needs to be addressed towards a more just world. Although the recent article by Story et al. (2017) focuses on health-related goals in UN SDG3, some of their results might be applicable all across the field. They provide a novel conceptual framework describing three ways how NGOs can add to the institutionalization of community-focused strategies. The first pathway is "learning for leverage" with NGOs demonstrating the effectiveness of innovations that can encourage changes. The second pathway is "thought leadership"; here NGOs disseminate new lessons learned toward public and private partners through teaching and information sharing. The third pathway, "joint venturing", denotes NGOs associating with governments to demonstrate the benefits of given project. NGOs use their collective voice to influence decision-makers. In addition, Story et al. (2017) specify six key drivers to fruitful institutionalization: responsiveness to national priorities, partnership with policymakers (as well as other stakeholders), community involvement, monitoring and utilization of gathered data, diversification of financial resources, and expectation for long-term results jointly with new funding schemes of long-term financing.

The extensive work of NGOs that has been instrumental in benchmarking companies against external ethical standards related to corporate responsibility, quality assurance and sustainability agendas, is often anchored in results of the applied business ethics research, especially in various tools and policies used on the mezzo level that is, in companies' internal environment. ${ }^{1}$ NGOs have participated in the creation of internal corporate standards and served also as a trend-setter for applied business ethics research. The collective pressure that NGOs have created toward corporate ethical conduct facilitated the implementation of ethics infrastructures and ethics programs in companies. Top managers and owners were more prone to implement codes of ethics, ethics offices and ethics \& compliance programs to document the pro-ethical orientation of their businesses.

Nevertheless, this close cooperation of NGOs with business is evident mostly in the western part of the world, while the Slovak (and as we assume also the CEE) experience differs to some extent. Slovak NGOs ensued just recently this trend with some projects that cover at the mezzo level the applied business ethics aspects. The specificity of Slovak NGOs lies in the fact that while a confrontational

\footnotetext{
${ }^{1}$ Currently, the applied business ethics research is one of the most quickly developing research agendas and since the 70 . of the $20^{\text {th }}$ century when this strand of applied research begun to spread from the US, thousands of articles were published, many of them in prominent journals like Journal of Business Ethics, Business Ethics Quarterly and Business Ethics: A European Review. This research agenda is vast and offers many practical solutions for companies to anchor their operations in ethics. For instance, the company ethics program is being acknowledged both in theory and practice as one of the most useful set of measures. Companies use ethics programs to encourage pro-ethical conduct and discourage unethical behavior (Jackson, 1997). Weaver and Trevino (1999) specified six ethics program elements that should form an ethics program, namely the code of ethics, ethics committee, communication systems, ethics officer, ethics training program and disciplinary process to solve unethical behavior. According to another prominent authority in this field of applied business ethics research, Kaptein, eight ethics program components should be considered, namely the code of ethics, ethics training and communication, accountability policies, monitoring and auditing, investigation and corrective policies, ethics office(r), ethics report line, and incentive policies (Kaptein, 2015).
} 
approach to business interests in evolving globalization was typical for NGOs in the 1990s, Slovak NGOs have focused primarily on building and improving civil society. They fulfilled the "watchdog" role in society that is they have focused somewhat unilaterally on creating pressure on the government, while the business was not subject of critical observation. Considering that, they dealt with the business environment only in a positive sense. This trend of NGOs serving primarily as a watchdog of governments with only minor attention paid to business has persisted up to the present. In other words, the "confrontational phase" towards business has been avoided by NGOs in our country. Interestingly, so far, NGOs have avoided also the phase of "cooperation with the business" that spread at the beginning of the $21^{\text {st }}$ century (Wieland 2009).

To capture the role and impact of NGOs on business ethics specifically in the Slovak society, we have focused primarily on NGOs concerned with civil society, excluding from our sample NGOs primarily dealing with environmental issues, ethnicity, sports, and culture as well as NGOs interconnecting various vocational professionals. Nowadays Slovak NGOs are primarily focused on civil society issues and a critical attitude towards government. Given the lack of sufficient data, it is difficult to predict now whether NGOs will concentrate on critical assessment of the business in the future and thus will become sort of a business watchdog, or whether they will soon transform into organizations that cooperate with business, respectively creating "cross-partnership" with business and government.

\section{Research Methodology}

Since research concerning specifically the impact of NGOs on business ethics is quite rare, a qualitative exploratory research framework was chosen for the purposes of this study. The investigation was based on two methods, namely (1) in-depth analysis of the researched NGOs' documentation to projects undertaken in Slovakia throughout the last two decades and (2) semi-structured face-to-face interviews with lead representatives of the respective NGOs. The data obtained by both methods were analyzed, compared, synthesized and interpreted in order to clarify the impact of prominent NGOs operating in Slovakia on the development of business ethics in the Slovak business environment.

The selection of NGOs was based on the research team's knowledge of the specifics of the Slovak non-governmental sector. The final sample entailed the most active NGOs in supporting ethical business practices in the Slovak business environment, namely the Against Corruption (AC), Alliance Fair-play (AFP), Institute for Economic and Social Reforms (INESR), Pontis Foundation (PON), Slovak Compliance Circle (SCC), Foundation Stop Corruption (SC), Transparency International Slovakia (TIS), and Via Iuris (VIAI). We have involved also the European Compliance Forum (ECF), which was not an NGO but a special initiative that was formed recently in 2017. Still, it has had an impact on the compliance-related discourse in the Slovak business environment with a potential to become a stable part of the Slovak non-governmental scene in the future. Table 1 presents a brief overview of the researched organizations: 
Table 1. Overview of the Researched NGOs

\begin{tabular}{|c|c|c|}
\hline NGOs/Est. since & Target groups & Main focus \\
\hline $\begin{array}{l}\text { Against } \\
\text { Corruption/2012 }\end{array}$ & $\begin{array}{l}\text { Politicians, state } \\
\text { authorities, public } \\
\text { organizations, the } \\
\text { civil society } \\
\text { (public) }\end{array}$ & $\begin{array}{l}\text { Provision of methodological and legal } \\
\text { assistance in the fight against corruption and } \\
\text { clientelism, offering qualified assistance to } \\
\text { citizens in identifying, detecting corruption, } \\
\text { organizing trainings on corruption, networking } \\
\text { between state and civil organizations fighting } \\
\text { corruption and clientelism, managing a } \\
\text { database of companies, organizations and } \\
\text { individuals who have been accused, or } \\
\text { convicted of corruption }\end{array}$ \\
\hline $\begin{array}{l}\text { Alliance Fair- } \\
\text { play/2002 }\end{array}$ & $\begin{array}{l}\text { Politicians, state } \\
\text { authorities, } \\
\text { state/public } \\
\text { organizations, the } \\
\text { civil society } \\
\text { (public) }\end{array}$ & $\begin{array}{l}\text { Democratization of civil society, pressure on } \\
\text { transparency of policymaking, disclosure of } \\
\text { information on conflict of interest of } \\
\text { politicians, transparency of the financial } \\
\text { environment and state management, } \\
\text { supervising the efficient use of public } \\
\text { finances, improving the law and the } \\
\text { functioning of the jurisdiction, supporting } \\
\text { public oversight of public affairs, supporting } \\
\text { investigative journalism and the overall } \\
\text { functioning of the media and their self- } \\
\text { regulation, promoting human rights and } \\
\text { citizens' political rights, connecting and } \\
\text { creating networks between citizens, NGOs, } \\
\text { professionals, the public sector, protection } \\
\text { and promotion of whistleblowers }\end{array}$ \\
\hline $\begin{array}{l}\text { Institute for } \\
\text { Economic and } \\
\text { Social } \\
\text { Reforms/1999 }\end{array}$ & $\begin{array}{l}\text { Politicians, } \\
\text { regulation bodies, } \\
\text { legislators, } \\
\text { economists }\end{array}$ & $\begin{array}{l}\text { Economic and social reforms, social policy, } \\
\text { approximation of Slovakia to the countries } \\
\text { of the Western Europe, research, } \\
\text { development and dissemination of } \\
\text { information and support for public debate on } \\
\text { economic and social issues, ranking and } \\
\text { rating of schools, health institutions }\end{array}$ \\
\hline $\begin{array}{l}\text { Pontis } \\
\text { Foundation/1997 }\end{array}$ & $\begin{array}{l}\text { Politicians, } \\
\text { judiciary, } \\
\text { prosecution, police, } \\
\text { state control } \\
\text { authorities, private } \\
\text { companies, other } \\
\text { NGOs, individuals' } \\
\text { philanthropic } \\
\text { activities }\end{array}$ & $\begin{array}{l}\text { Corporate social responsibility, individual } \\
\text { and corporate philanthropy, developing } \\
\text { cooperation with the Third World countries } \\
\text { and post-communistic countries in } \\
\text { disseminating democracy, education for } \\
\text { schools, companies, but especially for other } \\
\text { NGOs, promoting donations across the } \\
\text { society, funding projects of other NGOs, } \\
\text { networking with companies, other NGOs } \\
\text { and educational institutions }\end{array}$ \\
\hline $\begin{array}{l}\text { Slovak } \\
\text { Compliance } \\
\text { Circle/2013 }\end{array}$ & $\begin{array}{l}\text { Government, } \\
\text { representatives of } \\
\text { political parties, } \\
\text { private companies, } \\
\text { Slovak business }\end{array}$ & $\begin{array}{l}\text { Raising awareness of compliance, the roles } \\
\text { of a compliance officer, the importance of } \\
\text { business ethics in Slovakia, market research, } \\
\text { events for members (seminars), organization } \\
\text { of events for compliance experts (Slovak }\end{array}$ \\
\hline
\end{tabular}




\begin{tabular}{|c|c|c|}
\hline & $\begin{array}{l}\text { leaders, future } \\
\text { Slovak business } \\
\text { leaders (students) }\end{array}$ & $\begin{array}{l}\text { Compliance Days, seminars), preparation of } \\
\text { Slovak compliance standards, active } \\
\text { participation in the Rule of Law initiative, } \\
\text { working with young people }\end{array}$ \\
\hline $\begin{array}{l}\text { Stop Corruption/ } \\
2012\end{array}$ & $\begin{array}{l}\text { Politicians, state } \\
\text { authorities, public } \\
\text { organizations, the } \\
\text { civil society } \\
\text { (public) }\end{array}$ & $\begin{array}{l}\text { Anticorruption activities, development and } \\
\text { protection of spiritual and cultural values, } \\
\text { implementation and protection of human } \\
\text { rights, developing civil society, fulfillment } \\
\text { of individually designed humanitarian } \\
\text { assistance to individuals or groups of people } \\
\text { who have been threatened with life or need } \\
\text { urgent assistance in the event of a natural } \\
\text { disaster or a difficult life situation, } \\
\text { humanitarian activities }\end{array}$ \\
\hline $\begin{array}{l}\text { Transparency } \\
\text { International } \\
\text { Slovakia/1998/200 } \\
2^{*}\end{array}$ & $\begin{array}{l}\text { Slovak public, } \\
\text { local self- } \\
\text { government, } \\
\text { health institutions, } \\
\text { judiciary, public } \\
\text { companies, } \\
\text { individual citizens }\end{array}$ & $\begin{array}{l}\text { Providing assessments and } \\
\text { recommendations on the fight against } \\
\text { corruption, monitoring disclosure of state } \\
\text { contracts, surveying corruption, creating } \\
\text { portals for the best hospitals, judges, } \\
\text { transparency of public administration, legal } \\
\text { and moral assistance to whistleblowers, } \\
\text { preparing for the adoption of laws and their } \\
\text { amendments in the field of public } \\
\text { procurement, reporting of anti-social } \\
\text { activities, training for citizens interested in } \\
\text { transparency and corruption, training people } \\
\text { who are committed to fighting for more } \\
\text { transparent, effective and fair self- } \\
\text { government, control of public contracts, } \\
\text { preparing people for public control of local } \\
\text { self-government }\end{array}$ \\
\hline $\begin{array}{l}\text { Via Iuris/1993/ } \\
2006^{* *}\end{array}$ & $\begin{array}{l}\text { Judiciary, } \\
\text { prosecution, } \\
\text { police, } \\
\text { citizens/civil } \\
\text { society }\end{array}$ & $\begin{array}{l}\text { Independent activity of courts, prosecutors, } \\
\text { police, citizens' participation in public affairs, } \\
\text { transparency of Slovak justice, whistleblowers } \\
\text { protection, judge's personality, freedom of } \\
\text { expression, right to information, constitution in } \\
\text { judge's decision, personality development of a } \\
\text { judge, legislative initiatives, e.g. on the } \\
\text { publication of court decisions on the Internet } \\
\text { and on the availability of judicial decisions } \\
\text { upon request }\end{array}$ \\
\hline $\begin{array}{l}\text { European } \\
\text { Compliance } \\
\text { Forum/ } 2017^{* * *}\end{array}$ & $\begin{array}{l}\text { Members of } \\
\text { statutory boards } \\
\text { and senior } \\
\text { management }\end{array}$ & $\begin{array}{l}\text { Compliance management in corporate } \\
\text { practice }\end{array}$ \\
\hline
\end{tabular}

Source: Authors.

Notes: *1998 - Slovak subsidiary of the Transparency International; 2002 - Independent civic association titled Transparency International Slovensko. **1993 - Center for Environmental Public Advocacy; 2006 - Via Iuris. ***ECF is an initiative carried out in 2017 in ethics \& compliance programs in Slovak companies. 


\section{Analyzing the Content of NGOs' Projects}

As outlined above, this study employed two sources of empirical inquiry. First, we have analyzed the content of documentation related to projects undertaken by NGOs. More specifically, the content of webpages of the respective NGOs was thoroughly examined to find out which projects or individual activities were carried out by the NGOs and what proportion of these projects was dedicated specifically to the topic of business ethics. In the next step, the analysis aimed to specify the NGOs' best practices that were contributory for business ethics development. Furthermore, we wanted also to identify potential shortcomings in NGOs" activities, i.e. "empty spaces" to which more attention should be paid for the sake of a more vigorous development of ethics in the Slovak business environment in the future.

The scope of the reviewed material covered all information published between 1997 and 2017 at the NGOs' websites. This timeframe was chosen in order to attain a wider picture of various activities undertaken by the NGOs and how their initiatives have changed over time. The scope of reviewed material was enormous, so we have decided to focus on selected key terms with connotation to "business ethics". Our analysis has utilized following categories (in alphabetical order): clientelism; code of ethics; compliance; compliance program; conflict of interest; corporate citizenship; corporate social responsibility; corruption; discrimination; employee volunteering; ethical leadership; ethics; ethics infrastructure; ethics program; ethical regulation; fraud; fraudster; good corporate governance; managerial ethics; nepotism; philanthropy; stakeholder; sustainable development; transparency; whistleblowing.

In sum, twenty-five projects were identified and consecutively analyzed. Out of the nine NGOs, one did not have any projects related explicitly to business ethics; three NGOs each have delivered one project, two NGOs have had two business ethics-related projects, one NGO has delivered four different initiatives in business ethics, one NGO has had six projects and another NGO showed account of eight projects linked to business ethics. Topics covered by these projects related to code for good corporate governance with the aim to transfer good practices in managing companies from Western Europe to Slovak businesses, furthermore to corporate philanthropy, donations, volunteering service of company employees, and CSR promotion. Another portion of projects focused on surveying perceptions of business ethics, risks related to collaboration with questionable business partners, and corruption-related surveys. A good deal of projects concentrated on whistleblowing support and whistleblowers' protection. Several projects paid attention to compliance standards in business and best procurement practices particularly in relationship of private firms and the state.

\section{Conducting Semi-structured Interviews with NGOs' Leaders}

To complement the results of documentation-related analysis, the method of semi-structured interview was employed in this study. Interview questions were developed to mirror the main research inquiry to examine and critically 
reflect the nature, scope and effects of NGOs' activities in development of business ethics in Slovak companies.

For the purposes of this article, two main issues were addressed in the interviews. First, we were interested in what were the most successful projects carried out by the respective NGOs and in particular, what were the reasons of their added value for the development of business ethics in Slovakia. Second, on the other hand, we wanted to know which of the measures and tools promoted by the NGOs were not so fruitful in practice and what were the causes of their inferiority.

In addition, certain background and demographic data on research participants were collected. These entailed the title of the NGO, name of the NGO's representative who participated in this study, position that the participant fulfills in the respective NGO, representative's seniority (length of experience) with the NGO as well as his/her professional orientation (i.e. field of study). Last but not least, all participants were informed that their identities will be kept anonymous and were asked to authorize the transcribed interview results.

The interview sample consisted of nine NGOs' top representatives. All respondents except two worked in the NGOs on a permanent basis as full time employees. Six of the persons interviewed were male and three were female. Their positions in the researched NGOs varied due to differences in the NGOs' organizational structures; the sample consisted of six executive directors, one chairman of the board of directors, one managing partner, and one statutory chairman. As for the seniority within their NGOs, it has ranged from eight to fifteen years of work experience. In this period of time, two of interviewees served as top executives in the respective NGOs for less than one year, while the rest of them fulfilled top management position in the NGOs for more than three years. Their educational background was almost exclusively in social sciences with four participants studying one specialization and the rest studying in two or more specializations. Five research participants have studied journalism, three have studied management and economics, two were lawyers, four interviewees have studied politics, and one has studied history. They all were leading personalities in the NGO sector and dominant opinion makers with quite an influence in mass media. Therefore, we believe their views might inspire to see the problems associated with the development of business ethics in Slovakia in a new light.

The interviews were carried out in between October 2017 and January 2018 and each took approximately one hour. All interviews were subject to a uniform methodology to ensure consistency of approach across all researched NGOs. The participants' replies were recorded and then transcribed into Word for the purposes of a subsequent analysis. As it were all semi-structured interviews, it was highly desirable to respond to interviewees' answers and to pose sub-questions besides the predefined questions included in the interview scenario. Still, these subquestions have had to be in complete alignment with the basic research inquiries to keep the interviewee being focused on the subject matter. This enabled us to gather relevant and at the same time heterogeneous insights on the added value as well as on the potential deficiencies of NGOs' activities in business ethics development. 
After completion of the transcription of the face-to-face interviews and after anonymizing the personal information on individual participants, we have carefully analyzed their responses by using a qualitative approach to the interview material. In doing so, we have aimed to find common points of departure as well as differences in their subjective perceptions of ethics-related projects' effectiveness and related "success-or-failure" factors.

\section{Results and Discussion}

Given the analysis of participants' responses and after examining projects that, in our opinion, were directly related to the development of business ethics, we came to the conclusion that NGOs supported the development of business ethics in two main directions. On the one hand, NGOs offer companies knowhow in what way to create standards of ethical behavior and how to monitor these internally, and on the other hand, they offer companies the expertise how to deal with some serious unethical or illegal situations. Business ethics supporting projects of NGOs, thus, provide:

1. Guidelines and know-how to create ethical standards and programs that allow organizations to create a corporate code of ethics, a corporate governance code, to adopt ethics \& compliance program, to implement ethics and compliance officer position, to adopt the CSR concept, or an anti-corruption charter.

2. Know-how to the way how to proceed in case of whistleblowing and corruption in the organization, and how to report anti-social activity inside private as well as public organizations.

Our results indicate that the existence of these guidelines and knowledge is one aspect of the matter, however their adoption and application by Slovak businesses is a completely different thing. In the following section, we describe projects that NGOs themselves considered to be successful.

\section{Successful Projects}

One of the most successful projects refers to the creation of a transparency ranking of state-owned companies (companies owned by a state, city, or county). According to R3, the monitored companies are responding positively, and are actively trying to find out what they did wrong and how they can improve in the future. As for the ranking procedure, the assessed companies do not a priori approve to enter this evaluation, while the rating criteria together with the companies' ranking are published on the NGO's web. This is basically an indirect competition that does not burden the evaluated companies and does not require any additional activity from companies.

Another successful story regards a project caring for transparency in respect to pharmaceutical companies in Slovakia. As R3 has mentioned, in this project, 
pharmaceutical companies were urged to make public their contracts with hospitals in order to eliminate the payment of bonuses to doctors for prescription of certain medications. The underlying issue in this case was that pharmaceutical companies paid the bonuses to doctors, but hospitals used public financial sources to pay for medicaments to pharmaceutical companies. Thus, this project has eliminated potential source of corruption within the "state - hospitals pharmaceutical companies" chain.

Another positive response among state-owned enterprises was related to an anti-corruption audit project, in which the NGO (R3) carries out a thorough analysis of the company's internal processes to uncover risks of corruption.

A long-term project of awarding companies for exceptional implementation of corporate social responsibility in the Slovak business environment enjoys great popularity from the public. According to R2, paradoxically, this project is considered by the NGO itself to be less successful due to a relatively low number of companies signing up and competing to receive an award. This project has revealed that companies consider it problematic to go public with their internal activities.

Summarizing the views of our respondents, following activities were identified as successful business ethics supporting practices:

- Ranking of state-owned companies according to their transparency.

- Publishing contracts of hospital with pharmaceutical companies.

- Providing anticorruption audit in state-owned companies.

- Awarding companies for an exceptional approach to corporate social responsibility.

\section{Less Successful Projects}

Project aimed at adopting a code of corporate governance belongs according to R1 to the group of somehow less successful projects. In this project, although companies have been provided with a manual on how to proceed in order to implement a good corporate governance code, they have not really shown interest in adopting the code. The project developers concluded that "it was a sensitive issue for companies. They did not want to go 'deeper'. We have found out that companies need to be approached flexibly and they do not want to be forced into transparency."

Other NGOs have also indicated similar experiences in offering companies practical guidelines for codes of ethics or compliance and ethics programs. Small and medium-sized enterprises, in particular, were found to be not interested in this topic. As R4 has put it, "it is a task that does not have a clear 'owner'. It is not an attractive topic, so no one takes the initiative".

Educational projects were also considered as less effective, probably because their impact on the development of business ethics cannot be objectively gauged. The lack of an across-the-board support for business ethics was related also to an initiative known as the "Anti-corruption Charter", which did not attract much interest in the Slovak business environment (R3). 
In summary, the following projects were identified as somewhat less successful in terms of business ethics support:

- Developing the code for corporate governance.

- Adopting the Anti-corruption Charter.

- Lecturing (and other educational activities) related to business ethics, codes of ethics, or whistleblowing in companies.

\section{"Success-or-Failure” Factors}

In summing up the reasons why individual projects did not have the supposed reach in terms of impact, or why they were not given enough attention by the business environment, we noted a surprising leniency of NGOs toward the private companies. Given that, the dominant explanations were that "business is a sensitive issue, companies need to be treated flexibly, there is no need to push them into transparency" (R1) and that "the code contains excessively binding things, and managers often feel harmed if they are bound by strict rules" (R1). Furthermore, some NGOs reasoned that companies were reluctant to enter any competition or ranking because they were "afraid they will not pass ... [they have] feared that even despite the declared commitment to ethics in business and internally set guidelines or procedures, it may happen that some employees or managers were not correct" (R2).

Interestingly, we found out that as a reason for failure of a business-friendly business project, NGOs relatively often mentioned the concern of companies that ethics will harm them in that they will become less competitive. As R1 has said: "They are damaged because they lost part of their revenues against unethical businesses; this is connected with the deterioration of the competitive position on the market. Still, the influence of the environment is crucial in this respect, for example, if clients can appreciate that the company is ethical then it's ok for the business".

With regard to less successful ethics-related projects, the respondents also felt that entrepreneurs are skeptical about new ideas. They must first have confidence in ethics; thus, we need to "explain to companies in their own language what business ethics is and why it is important" (R2).

Considering that the reasons for failure of some business ethics projects, which NGOs have outlined, do correspond with the Slovak business reality and entrepreneurial mentality, it can be concluded that Slovak business environment is worried with ethics. Ethics in business is perceived as a factor that limits or narrows the business environment and not as a factor inseparably connected with the business environment.

Evidently, Slovak business environment is tainted by the idea that if ethics harms the business, the entrepreneur will simply not implement it. We believe this idea is in sharp contrast with the very essence of business. This attitude was also expressed by R3 who came to the conclusion that regarding corruption, many entrepreneurs assume that: "Getting the benefits for oneself is stronger than knowing that the economic competition will be damaged". 
In conclusion, our findings on successful business ethics projects show that:

- All projects that were rated as successful did not directly engage companies to get involved, but companies became respondents to research without their active participation - a typical example is the compilation of the list of transparent companies. This means that companies are not "pushed" into any "pro-ethical" activities.

- Projects did not require companies to take responsibility for active ethical changes or standards to become active carriers of change. follows:

On the other hand, our conclusions in respect to unsuccessful projects are as

- All unsuccessful projects required from business subjects a substantial amount of transparency, meaning that internal process of companies would get public attention.

- All unsuccessful projects required management to in charge for change in the pro-ethical internal corporate environment and to take responsibility for adopting ethical standards.

\section{Conclusions}

NGOs in Slovakia have done a tremendous job in building a democratic open society. They have helped generate awareness of the harmfulness of corruption in society and showed the public that corruption can fought against and that there are many mechanisms leading to its limitation. They have expanded and consolidated new values in social life - both political and economic - especially transparency and the right to information; and persuaded the population about the importance of respecting these values in a legal and democratic state.

Of the surveyed NGOs, only two were directly focused on supporting the development and promotion of business ethics in companies. Nevertheless, our analysis showed that NGOs have implemented a wide range of projects to support the development of business ethics in the Slovak environment. Still, results indicate a shortage of attention to ethics in human resource management, to the control of illegal and unethical activity within the company and to unethical leadership and related negligence of the tone at the top of companies. Outcomes of this study on the best practices and unsuccessful projects developed by NGOs for business ethics support are opening up challenging questions for prospective research. Why do Slovak businesses have concerns about transparency? Why do Slovak entrepreneurs understand ethics as a harmful factor for their business? Why do Slovak companies refuse to accept responsibility for their own ethical development? How to stimulate the interest of Slovak companies in active promotion of ethics in their organization? 


\section{Acknowledgments}

This work was supported by the Slovak Research and Development Agency under the contract no. APVV-16-0091.

\section{References}

Arenas D, Lozano JM, Albareda L (2009) The role of NGOs in CSR: Mutual perceptions among stakeholders. Journal of Business Ethics 88: 175-197.

Asi YM, Williams C (2018) The role of digital health in making progress toward Sustainable Development Goal (SDG) 3 in conflict-affected populations. International Journal of Medical Informatics 114: 114-120.

Baur D, Palazzo G (2011) The moral legitimacy of NGOs as partners of corporations. Business Ethics Quarterly 21: 579-604.

Baur D, Schmitz HP (2012) Corporations and NGOs: When accountability leads to cooptation. Journal of Business Ethics 106: 9-21.

Bergman MM, Bergman Z, Berger L (2017) An empirical exploration, typology, and definition of corporate sustainability. Sustainability (Switzerland) 9: 1-13.

Burgos S (2013) Corporations and social responsibility: NGOs in the ascendancy. Journal of Business Strategy 34: 21-29.

Choi CJ, Cheng P, Kim JB, Eldomiaty TI (2005) Dual responsibilities of NGOs: Market and institutional responsibilities and ethics. The Journal of Corporate Citizenship 17 (Spring 2005): 26-29.

Egels-Zanden N, Wahlqvist E (2007) Post-partnership strategies for defining corporate responsibility: The business social compliance initiative. Journal of Business Ethics 70: $175-189$.

Jackson KT (1997) Globalizing corporate ethics programs: Perils and prospects. Journal of Business Ethics 16: 1227-1235.

Jamali D, Keshishian T (2009) Uneasy alliances: Lessons learned from partnership between businesses and NGOs in the context of CSR. Journal of Business Ethics 84: 277-295.

Jimena J (2009) There's nothing standard about standardization. Canadian Mining Journal 130: 8.

Jonker J, Nijhof A (2006) Looking through the eyes of others: Assessing mutual expectations and experiences in order to shape dialogue and collaboration between business and NGOs with respect to CSR. Corporate Governance 14: 456-466.

Kaptein M (2015) The effectiveness of ethics programs: The role of scope, composition, and sequence. Journal of Business Ethics 132: 415-431.

Kourula A, Halme M (2008) Types of corporate responsibility and engagement with NGOs: An exploration of business and societal outcomes. Corporate Governance 8: 557-570.

Laasonen S, Fougere M, Kourula A (2012) Dominant articulations in academic business and society discourse on NGO-business relations: A critical assessment. Journal of Business Ethics 109: 521-545.

Li DD, Feng, J, Jiang H (2006) Institutional entrepreneurs. The American Economic Review 96: 358-362.

Levy DL, Brown H, de Jong M (2010) The contested politics of corporate governance: The case of the global reporting initiative. Business and Society 49: 88-115. 
Moon J (2002) The social responsibility of business and new governance. Government and Opposition 37: 385-408.

Noh JE (2017) The role of NGOs in building CSR discourse around human rights in developing countries. Cosmopolitan Civil Societies 9: 1-19.

Putnam R, Leonardi R, and Nanneti R (1993) Making Democracy Work: Civic Traditions in Modern Italy. Princeton: Princeton University Press.

Reichel J, Rudnicka A (2009) Collaboration of NGOs and business in Poland. Social Enterprise Journal 5: 126-140.

Remišová A (2011) Etika a ekonomika [Ethics and Economics]. Bratislava: Kalligram.

Remišová A (2015) Súčasné trendy v podnikatel'skej etike [Current Trends in Business Ethics]. Bratislava: Wolters Kluwer.

Remišová A, Lašáková A, Rudy J, Sulíková R, Kirchmayer Z, Fratričová J (2016) Ethical Leadership in Slovak Business Environment. Praha: Wolters Kluwer.

Story WT, LeBan K, Altobelli LC, Gebrian B, Hossain J, Lewis J, Morrow M, Nielsen JN, Rosales A, Rubardt M, Shanklin D, Weiss J (2017) Institutionalizing communityfocused maternal, newborn, and child health strategies to strengthen health systems: A new framework for the Sustainable Development Goal era. Globalization and Health 13: 1-13.

Weaver GR, Trevino LK (1999) Corporate ethics program as control systems: Influences of executive commitment and environmental factors. Academy of Management Journal 42: 41-57.

Weber K, Soderstrom SB (2015) Sustainability discourse and capitalist variety: A comparative institutional analysis. In Corporate Social Responsibility in a Globalizing World, Tsutsui K, Lim A (Eds.), Cambridge University Press, Cambridge, 218-248.

Wieland C (2009) NGOs and businesses. Move from conflict to cooperation. Colombia Internacional 69: 86-107.

Xiao Y, Norris CB, Lenzen M, Norris G, Murray J (2017) How social footprints of nations can assist in achieving the Sustainable Development Goals. Ecological Economics 135: 55-65. 